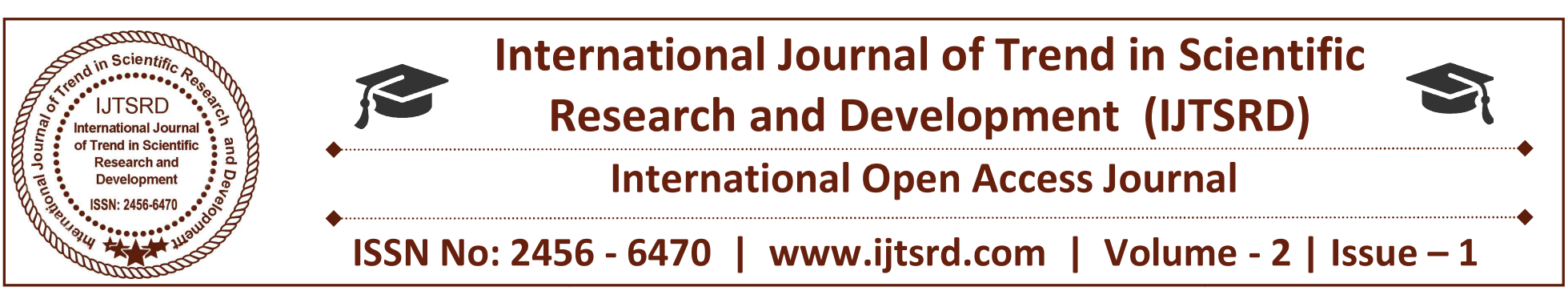

\title{
Unclaimed Dividend, Profitability and Firm Value of Quoted Deposit Money Banks (DBMS) in Nigeria
}

\author{
Prof. C. M. Ekwueme \\ Professor of Accounting, Nnamdi Azikiwe \\ University, Awka, Anambra State, Nigeria
}

\author{
Ezelibe Chizoba Paulinus \\ Ph.D Student, Department of Accountancy, Nnamdi \\ Azikiwe University, Awka
}

\section{ABSTRACT}

This study seeks to examine the effect of unclaimed dividend on profitability and firm value of selected deposit money banks (DMBs) quoted in the Nigerian Stock Exchange (NSE). The population of constitutes of all the quoted deposit money banks (DMBs) in the Nigerian Stock Exchange for the 5 year period (20122016) covered by this study. Nine of the banks were selected was selected for the study. Ordinary least square (OLS) statistical tool was used in the analysis of data. The study found that there is no significant relationship between unclaimed dividend and profitability, similarly it was also observed that no significant relationship exists between unclaimed dividend and firm value of the selected banks. It was recommended that regulators and other stakeholders in the capital market should ensure that the new edividend payment system is fully implemented to significantly reduce the volume of unclaimed dividend. Also, shareholders should be sensitized on the importance of the e-dividend payment and how they can take advantage of it.

Keywords: unclaimed dividend, profitability, firm value, quoted banks, tobin $q$

\section{Introduction}

The motivation behind any investment in the shares of a company can either be achieved by taking advantage of fluctuation in the prices of shares invested in or taking part in profit sharing through dividend. Over the years, especially in Nigeria, investors for dividend face a lot of problems with regard to converting their dividend warrants to cash which leads to consistent increase in unclaimed dividend.

The incidence of unclaimed dividend in the Nigerian Stock Market has remained a major concern among stakeholders in the capital market. In spite of the several efforts of the apex market regulator, the Securities and Exchange Commission (SEC), the problem seems far from over. In an effort to ameliorate the problem of unclaimed dividend, the SEC in June, 2008 launched the e-payment system which involves dividend payment through into shareholder's nominated bank through a direct credit rather than through cheques or warrant. Owolabi and Obida (2013) rightly described that regulators made some frantic efforts to curtail the incidences of unclaimed dividend by introducing the E-dividend system of payment on June 16, 2008 which was meant to address the delay associated with the verification of proceeds of public offers as well as delay encountered by investors in getting returns on their investment and also reduce the incidence of unclaimed dividend but so far, the way and manner it is being implemented by most of the registrars and the failure of shareholders to fully embrace the e-dividend initiative have continued to increase the incidence of unclaimed dividend. This situation no doubt defeats one of the purposes of investing in such a company and poses a major threat to potential investments.

Subsequent effort by the SEC to address this issue led to proposing a rule earlier in 2015 that all unclaimed dividend in the custody of the Registrars shall be 
returned to the paying company twelve (12) months after the date of approval of dividend at a general meeting. It also ensured that the Nigerian capital market regulator, the Security and Exchange Commission (SEC) launched a system known as the EDividend Mandate Management System (E-DMMS) in collaboration with the Central Bank of Nigeria, Nigerian Interbank Settlement System (NIBSS) and other stakeholders in July 29, 2015 to enable investors complete their bank mandate with company registrars with ease and less stress (Proshare, 2015).

Gwarzo (2016) noted that the migration from manual warrant divided to e-dividend system was aimed at addressing the alarming accumulation of unclaimed dividend in the capital market and to help reduce the amount which stood at N117 billion as at December 31, 2016. Out of this figure, N86 billion was in the custody of the paying companies while N13.7 billion was in the custody of the registrars. From November 2015 when the SEC flagged-off the campaign using the new edividend payment system to February 2017, about N42.2 billion has been paid to investors from the backlog of unclaimed dividend. About 2.2 million investors have so far mandated their bank accounts for direct payment of dividend through the e-dividend platform with about 9 million investors yet to join the e-dividend system where dividend will be paid directly by corporate registrars to the bank accounts of investors (Ekwueme \& Omenka, 2017). SEC had earlier announced June, 2017 as deadline for issuance of physical dividend warrants and cheques but later extended the date to $31^{\text {st }}$ December, 2017 to accommodate more shareholders that are yet to register for the e-payment system.

\section{Statement of the Problem}

Corporate organisations are saddled with a major responsibility of shareholders' wealth maximization. They have three major decisions to make which includes investment decision, financing decision and dividend decision. The dividend decision has to do with the determination of the dividend policy adopted by the firm in deciding the amount of cash that is given to shareholders. It can be seen therefore that the dividend policy adopted by a company is instrumental to achieving their objective of profit and shareholders' wealth maximization.

Profitability and value maximization are the operational phenomenon of every profit making organization and constitutes the short and long-run management planning and operating strategies. It is a qualitative measure of input-output relationship of management and management efficiency in maximizing investor (Akani \& Sweneme, 2016).

There have been attempts to establish a valued and acceptable relationship between dividend policy, firm value and profitability of quoted firms in Nigeria. The emphasis has been on dividend per share and dividend payout ratio. However given the increasing amounts of unclaimed dividend and the various efforts of the stakeholders in the stock market to nip it in the bud, this study seeks to fill the gap in literature by examining the effect of unclaimed dividend on profitability and firm value of selected deposit money banks (DMBs) quoted in the Nigerian Stock Exchange (NSE). Based on the foregoing, this study seeks to determine the effect of unclaimed dividend on profitability and firm value of quoted deposit money banks (DMBs) in Nigeria.

The following hypotheses are formulated to guide the study.

$\mathrm{H}_{\mathrm{o}}$ : There is no significant relationship between unclaimed dividend and net profit of quoted deposit money banks (DMBs) in Nigeria.

$\mathrm{H}_{\mathrm{o}}$ : Unclaimed dividend has no significant relationship with Firm value of quoted deposit money banks (DMBs) in Nigeria.

\section{Literature Review}

\section{Unclaimed Dividend in Nigeria}

The history of unclaimed dividend can be traced to as far back as 1972 with the establishment of the Nigerian Stock Exchange (NSE). Those early periods were bedevilled by the paucity of trading systems for keeping track of share certificate and signatures and with 12 years ultimatum by Companies and Allied Matters Acts (CAMA) to declare dividend status barred marked the beginning of the growth of unclaimed dividend in Nigeria.

The major causes of unclaimed dividend as listed by Nwachukwu (2011), Mgboji (2011) and Akinkugbe (2011) and cited in the works of Owolabi and Obida (2013) are stated below.

- Non-Receipt of Dividend Warrant Timely

- Uninformed Investors

- Deliberate Plans by Companies

- Death of a Shareholder

- Meagre Amount/Non-Presentation of dividend

- No Bank Account 
International Journal of Trend in Scientific Research and Development (IJTSRD) ISSN: 2456-6470

- Inefficiency of the Registrars

- Defective Postal System/Unstable Addresses of the Shareholders

\section{Electronic Dividend Payment System}

From November 2015 when the SEC flagged off the campaign on e- dividend to February 2017, about N42.2 billion has been paid to investors from the backlog of unclaimed dividend. About 2.2 million investors have so far mandated their bank accounts for direct payment of dividend through the e-dividend platform with about 9 million investors yet to join electronic-dividend system where dividend will be paid directly by corporate registrars to the bank accounts of investors (Ekwueme \& Omenka, 2017).

There are more than 12 million investors in the stock market. Of this number, Minority retail investors account for more than 80 per cent of the domestic investors' base, although they account for lower turnover. Institutional investors, including pension fund administrators (PFAs), insurance companies, investment banking firms, stockbrokers, dealers and high net worth individual investors among others, account for the larger percentage of transactions. Transactional report by the Nigeria Stock Exchange (May 2017) indicated that retail domestic investors account for 38.5 per cent of total transaction value by domestic investors. Many sources in the know said the large number of unregistered investors for the edividend might have been responsible for the extension of the June 30, 2017 deadline for the cessation of dividend warrants and adoption of the full e-dividend option by SEC (Ekwueme \& Omenka, 2017).

Electronic dividend has a number of benefits attributed to its adoption and implementation. Some of these benefits as identified by Gwarzo (2016) includes the following:

- It is convenient, secure, online means of paying dividend directly to the investor

- Shareholders will receive their dividend promptly, without the hassles of lodging or cashing their cheques or warrants in banks.

- Increase transparency and efficiency in the administration of dividend payment.

- Investors will be able to monitor and tract dividend payments more effectively.

- Faster and more secured dividend payments shareholders will get credit for dividend declared within 24 hours of payment.
- More investors will be attracted into the capital market.

- More satisfied investors as dividend are received promptly.

- It implies same day clearance for dividend payment, following which a confirmation letter of the dividend payment is then sent to the shareholder through the Registrars.

- No more waiting for the dividend warrant in the mail or queuing to pay in the bank.

- Eliminate the forfeiture of dividend in the future.

- Enhance ability of shareholders to immediately access and utilize the proceeds of their investments for reinvestment.

- In additional, Gwarzo also identified the demerits of physical dividend warrant to include:

- Shareholders who die intestate without a share certificate and did not indicate any information on their next of kin will lose their entitlements.

- There can be a deliberate act to deny investors their benefit through various schemes by companies who lack liquidity to pay and/or have to borrow to pay.

- There is common cases of poor logistics management and inadequate update of personal data on the part of shareholders.

- In event of change of address of shareholders, wrong or incomplete mailing addresses of shareholders kept by Registrars have prevented them from getting their dividend.

- Small dividends are abandoned for not being worth the effort to collection.

\section{Theoretical Framework}

A number of theories have been postulated to support the subject of dividend and dividend policy. Such theories include dividend irrelevancy theory proposed by Modigliani and Miller, Walters's model of dividend policy, residual theory, the bird in the hand theory and Gordon's dividend policy. Gordon's dividend policy theory is however adopted for the purpose of this study. This is because of its emphasis on share price valuation method on the basis of future streams of dividend.

\section{Gordon Theory}

The Gordon theory introduced the concept of dividend relevance when ascertaining the market value of shares. The theory is known for its mathematical models in calculating the market value of a company's share. It states that the market value of a company is equal to the present value of future streams of dividend. To 
determine the market value of a company, the variables considered include dividend, the cost of fund and expected growth rate.

According to Adesina, et al (2017), the Gordon theory is based on the following assumptions:

Absence of debt in capital structure of the firm;

Investments are financed through retained earnings, no external financing.

There is no tax.

The absence of business risk.

Also, according to this theory, dividend policy impacts the company in the following circumstances.

i. If the rate of return is higher than the cost of fund, profits are reinvested for future growth rather than distributing it as a dividend.

ii. If the internal rate of return is same as the cost of the fund, reinvestment of earnings or payment of dividend out of earnings makes no difference.

iii. If the rate of return is lower than the cost of fund, the firm distributes profits in the form of a dividend.

Even though this theory has attracted criticisms, it has also been found out to provide a reliable model for the valuation of the market value of a company. It agrees with the submission of some researchers that dividend play an important role in share price valuation and profitability (Adesina, et al 2017; Baker, Veit, \& Powell, 2001). It is based on the foregoing that this study investigates how unclaimed dividend affects the value of the firm and their profitability.

\section{Empirical Review}

Oyejide, (1978) in his study found a statistical significant relationship between current year dividend and past year net profit. Adelegan, (2003) pointed out that factors such as after tax earnings, economics policy changes, firm's growth potentials and long term debts influence the dividend policy of quoted firms in Nigeria. Adelegan, (2009) also found out that the cumulative excess returns for dividend paying firms were positive and significant for 30 days from the day of the announcement of dividend payments, while the same excess returns for dividend omitting firms for the same period were significantly negative.

Uwuigbe, Jafaru \& Ajayi, (2012) found out that there is a significant positive association between the performance of firms and the dividend payout of the sampled firms in Nigeria. The empirical results of the study by Hashemijoo, Ardekani, \& Younesi, (2012) showed a significant negative relationship between share price volatility and two measurements of dividend policy which are dividend yield and dividend payout ratio.

Adefila, Oladapo and Adeoti (2004) in their own study, found no correlation between dividend payment and share prices of Nigerian firms as share price fixing, according to them is regulated by the Security and Exchange Commission (S.E.C) in respect of the quoted companies. But then, their findings show that Nigerian firms do have a dividend policy that is dependent on earnings albeit inconsistently.

Duke, Ikenna and Nkamare, (2015) found that dividend yield had a significantly positive effect on share price while retention ratio was found to have a significantly negative effect on it. The study recommended that banks should ensure that they have an optimal robust dividend policy in place. Regular update of records of shareholders should be made to avoid a deliberate diversion or undue retention of unclaimed dividend warrants. Government should set up a body that will help to manage unclaimed dividend and also ensure that situations that give rise to such are minimized.

Adediran and Alade (2013) ascertained the relationship between dividend policy and corporate profitability, Investment and Earning per Shares. Findings indicate that; there is a significant positive relationship between dividend policies of organizations and profitability, there is also a significant positive relationship between dividend policy and investments and there is a significant positive relationship between dividend policy and Earnings per Share.

Owolabi and Obida, (2013) found that various reasons are attributed to the increase in unclaimed dividend. Some of these reasons include: death of shareholders, change of address by investors, loss of dividend warrant on transit. In order to understand the dynamics of unclaimed dividend descriptive statistic was used to analyze data from First Bank of Nigeria (FBN) for the period of ten years. It was discovered that unclaimed dividend is increasing geometrically.

Ekwueme and Omenka, (2017) surveyed the public perceptions of e-dividend and payment system in the Nigerian capital market. Data were collected from both primary and secondary sources. The major data 
collection instrument is the questionnaire and interviews. On presentation and analysis of data, the study found among other things that awareness of edividend payment system in the Nigerian capital market among the stakeholders was sufficient. This was evidence in the perception of investors in the Nigerian capital market where $60 \%$ of respondents affirmed that there is sufficient dissemination of information on the e-divided policy.

Adesina, Uwuigbe, Uwuigbe, Asiriuwa and Oriabe, (2017) examined dividend policy and share price valuation in the Nigerian banks. Findings from the study show that a significant positive relationship exist between earnings per share and market price. The study concluded that banks should put in place efficient and robust dividend policy and leverage on the new edividend payment initiative for a better performance.

\section{Methodology}

The ex-post facto research design was adopted for this study. The population of this study constitutes of all the quoted deposit money banks (DMBs) in the Nigerian Stock Exchange for the 5 year period $(2012$ - 2016) covered by this study. Nine of the banks were selected because they disclosed values of unclaimed dividend for the years under study. These banks therefore constitute the sample size of the study. The annual reports of nine banks (Diamond, FBN, Fidelity, Access, GTBank, Zenith, Stanbic, FCMB and UBA) for the period 2012-2016 were obtained and analysed in order to realise the objective of the study. The study employed ordinary least square (OLS) statistical tool in the analysis of data. Tobin Q is used to measure the value of the firm while net profit is used to measure profitability.

TOBIN's $\mathrm{Q}_{\mathrm{it}}$ : is the ratio of market capitalization to the book value of assets for firm $i$ in period $t$. It is a measure that combines market performance with book values.

\section{Model Specification}

A model was formulated for the purpose of this study which was adopted from the research carried out by Adesina et al (2017) on dividend policy and share price valuation in Nigerian banks. The model was adapted because it establishes a relationship between dependent and independent variables. In this study, while firm value and Profitability represents a dependent variable, unclaimed dividend is the independent variable. The model specification is as stated under:

FVLit $=f(U C D i t)$

PRFit $=f(U C D i t)$

The model is further express as follows;

FVLit $=\beta_{0}+\beta_{1} U C D_{i t}+\alpha$

PRFit $=\beta_{2}+\beta_{3} U C D_{i t}+\alpha$

\section{Where:}

$F V L=$ Firm value

$U C D=$ Unclaimed Dividend

$P R F=$ Profitability

$\alpha=$ Stochastic Error Term

Data Analysis and Discussion of Findings

Table 1 Model Summary
\begin{tabular}{|l|l|l|l|l|}
\hline Model & R & R Square & Adjusted R Square & $\begin{array}{l}\text { Std. Error of the } \\
\text { Estimate }\end{array}$ \\
\hline 1 & $.062^{\mathrm{a}}$ & .004 & -.019 & .40545 \\
\hline
\end{tabular}
a. Predictors: (Constant), Unclaimed div




\begin{tabular}{|c|c|c|c|c|c|c|}
\hline \multicolumn{7}{|c|}{ Table 2 ANOVA ${ }^{a}$} \\
\hline \multicolumn{2}{|c|}{ Model } & Sum of Squares & df & Mean Square & $\mathbf{F}$ & Sig. \\
\hline \multirow[t]{3}{*}{1} & Regression & .027 & 1 & .027 & .164 & $.687^{\mathrm{b}}$ \\
\hline & Residual & 7.069 & 43 & .164 & & \\
\hline & Total & 7.096 & 44 & & & \\
\hline \multicolumn{7}{|c|}{ a. Dependent Variable: net profit } \\
\hline \multicolumn{7}{|c|}{ b. Predictors: (Constant), Unclaimed div } \\
\hline
\end{tabular}

\section{Table 3 Coefficients ${ }^{\mathrm{a}}$}

\begin{tabular}{|c|c|c|c|c|c|c|}
\hline \multirow{2}{*}{\multicolumn{2}{|c|}{ Model }} & \multicolumn{2}{|c|}{$\begin{array}{l}\text { Unstandardized } \\
\text { Coefficients }\end{array}$} & \multirow{2}{*}{$\begin{array}{l}\text { Standardized } \\
\text { Coefficients } \\
\text { Beta }\end{array}$} & \multirow[t]{2}{*}{$\mathrm{t}$} & \multirow[t]{2}{*}{ Sig. } \\
\hline & & B & Std. Error & & & \\
\hline \multirow[t]{2}{*}{1} & (Constant) & 10.494 & .112 & & 93.926 & .000 \\
\hline & $\begin{array}{l}\text { Unclaimed } \\
\text { div }\end{array}$ & .006 & .015 & .062 & .406 & .687 \\
\hline
\end{tabular}

\section{Table 4 Model Summary}

\begin{tabular}{|l|l|l|l|l|}
\hline Model & $\mathrm{R}$ & R Square & Adjusted R Square & $\begin{array}{l}\text { Std. Error of the } \\
\text { Estimate }\end{array}$ \\
\hline 1 & $.127^{\mathrm{a}}$ & .016 & -.007 & .10162 \\
\hline
\end{tabular}

\begin{tabular}{|c|c|c|c|c|c|c|}
\hline \multicolumn{2}{|c|}{ Model } & \multirow{2}{*}{$\begin{array}{l}\text { Sum of Squares } \\
.007\end{array}$} & \multirow{2}{*}{$\begin{array}{l}\mathrm{df} \\
1\end{array}$} & \multirow{2}{*}{$\begin{array}{l}\text { Mean Square } \\
.007\end{array}$} & \multirow{2}{*}{$\begin{array}{l}\text { F } \\
.710\end{array}$} & \multirow{2}{*}{$\begin{array}{l}\text { Sig. } \\
.404^{b}\end{array}$} \\
\hline 1 & Regression & & & & & \\
\hline & Residual & .444 & 43 & .010 & & \\
\hline & Total & .451 & 44 & & & \\
\hline \multicolumn{7}{|c|}{ a. Dependent Variable: tobin $\mathrm{q}$} \\
\hline
\end{tabular}


International Journal of Trend in Scientific Research and Development (IJTSRD) ISSN: 2456-6470

\section{Table 7 Coefficients ${ }^{2}$}

\begin{tabular}{|c|c|c|c|c|c|c|}
\hline \multicolumn{2}{|c|}{ Model } & \multicolumn{2}{|c|}{$\begin{array}{l}\text { Unstandardized } \\
\text { Coefficients }\end{array}$} & \multirow{2}{*}{$\begin{array}{l}\text { Standardized } \\
\text { Coefficients } \\
\text { Beta }\end{array}$} & \multirow[t]{2}{*}{$\mathrm{t}$} & \multirow[t]{2}{*}{ Sig. } \\
\hline & & B & Std. Error & & & \\
\hline \multirow[t]{2}{*}{1} & (Constant) & .098 & .028 & & 3.497 & .001 \\
\hline & $\begin{array}{l}\text { Unclaimed } \\
\text { div }\end{array}$ & .003 & .004 & .127 & .842 & .404 \\
\hline
\end{tabular}

a. Dependent Variable: tobin $\mathrm{q}$

The findings from the regression analysis for the first hypothesis shows $\mathrm{R}^{2}$ which otherwise known as the coefficient of determination of the variables as .004 . The R-Squared which equally measures the overall fitness of the model indicates that the unclaimed dividend is almost incapable of explaining the variability in the profitability of the banks.

Similarly, findings from the Fishers ratio (i.e. the FStatistics which shows the validity of the estimated model) as reflected in table 2 , presents a $p$ value that is greater than 0.05 ( $\mathrm{p}$-value $>0.05$ ); this invariably suggests clearly that the predictor variable is not significantly associated with the dependent variable, profitability. We therefore accept the null hypothesis that there is no significant relationship between unclaimed dividend and net profit.

The result in table 3 presents a positive and insignificant relationship between unclaimed dividend and net profit. This is shown in the t-statistics value of 0.406 and a p-value $=0.687$. This implication of this finding is that the value of unclaimed dividend does not affect the profitability of the quoted deposit money banks (DMBs) in Nigeria.

Similarly, the finding from the second hypothesis shows $\mathrm{R}^{2}$ which otherwise known as the coefficient of determination of the variables as .016 . The R-Squared which equally measures the overall fitness of the model indicates that the unclaimed dividend is almost incapable of explaining the variability in the market value of the banks.

The Fishers ratio (i.e. the F-Statistics which shows the validity of the estimated model) as shown in table 5, presents a $\mathrm{p}$ value that is greater than 0.05 ( $\mathrm{p}$-value $>$ 0.05 ); this invariably suggests clearly that the predictor variable, unclaimed dividend is not significantly associated with the dependent variable, firm value. We therefore accept the null hypothesis that unclaimed dividend has no significant relationship with Firm value.

The result in table 6 presents a positive and insignificant relationship between firm value and unclaimed dividend. This is shown in the t-statistics value of 0.842 and a $p$-value $=0.404$. The implication is that the market value of the banks is not affected by the unclaimed dividend. This result is in agreement with the findings of Adesina et al (2017) and Adefila, Oladipo \& Adeoti (2004) that there is no correlation between dividend and market value of shares.

\section{Conclusion and Recommendation}

The study examined the how unclaimed dividend affect profitability and firm value of quoted deposit money banks (DMBs) in Nigeria. The study found that there is no significant relationship between unclaimed dividend and profitability; similarly it was observed that no significant relationship exists between unclaimed dividend and firm value of the selected banks. This outcome therefore, suggests that the incidence of unclaimed dividend has no impact on the profitability and firm value. Though the incidence of unclaimed dividend does not affect the value of the banks, it no doubt defeats the purpose of shareholders investment. Regulators and other stakeholders in the capital market should ensure that the new e-dividend payment system is fully implemented to significantly reduce the volume of unclaimed dividend. Also, shareholders should be sensitized on the importance of the e-dividend payment and how they can take advantage of it.

\section{References}

1. Adediran S.A. \& Alade S.O. (2013) Dividend Policy and Corporate Performance in Nigeria. American Journal of Social and Management Sciences, doi:10.5251/ajsms.2013.4.2.71.77 
2. Adefila, J.J., Oladapo, J.A. \& Adeoti, J.O. (2004). The effect of dividend policy on the market price of shares in Nigeria: case study of fifteen quoted companies. Retrieved from http://unilorin.edu.ng/publications/adeotijo/THE\%2 0EFFECT\%20OF\%20DIVIDEND\%20POLICY.pd $\mathrm{f}$

3. Adelegan, O. (2003). The impact of growth prospect, leverage and firm size of dividend behavior of corporate firms in Nigeria. The centre for econometric and allied research UI, Nigeria

4. Adelegan, O.J. (2009). Price reactions to dividend announcements on the Nigerian stock market. AERC Research Paper 188, African Economic Research Consortium, Nairobi

5. Adesina, K., Uwuigbe, U., Uwuigbe, O.R., Asiriuwa, O. \& Oriabe, S. (2017) Dividend Policy and Share Price Valuation in Nigerian Banks. Euro Economica 1(36)

6. Akani, H.W. \& Sweneme, Y. (2016) Dividend Policy and the Profitability of Selected Quoted Manufacturing Firms in Nigeria: An Empirical Analysis. Journal of Finance and Accounting. Vol. 4, No. 4, 2016, 212-224. doi: 10.11648/j.jfa.20160404.17

7. Baker, H.K., Veit, E.T., \& Powell, G.E. (2001). Factors influencing dividend policy decisions of Nasdaq firms. Financial Review, 36(3), 19-38.

8. Proshare, (2015). The launch of the new e-dividend mandate management system. The Nigerian Investor, Thursday, July 30, 2015. Retrieved from http://www.proshareng.com/news/ Products\%20/The-Launch-of-the-NewProshare/28022

9. Duke, S.B., Ikenna, N.D., \& Nkamare, S.E. (2015). Impact of Dividend Policy on Share Price Valuation in Nigerian Banks. Archive of Business Research, $3(1)$ $156-170$

URL:http://dx.doi.org/10.14738/abr.31.840.162

10. Ekwueme, A.C. \& Omenka, J.O. (2017). Public Perception of Electronic Dividend on the Nigerian Capital Market Development. Global Journal of Human-Social Science 17(4)

11. Gwarzo, M. (2016). Paper Presented at a Town Hall meeting to sensitize the investing public on the electronic divided policy held at the International Conference Centre, Abuja.
12. Hashemijoo, M., Ardekani, A.M. \& Younesi, N. (2012). The impact of dividend policy on share price volatility in the Malaysian stock market. Journal of business studies quarterly, 4(1), 119-129.

13. Owolabi, S.A. \& Obida, S.S. (2013). Unclaimed dividend: matters arising. Singaporean Journal of Business Economics, and Management Studies 1(6).

14. Oyejide, T.A. (1978). Company dividend policy in Nigeria: An empirical analysis. The Nigerian journal of economic and social studies, 18(2): 179194.

15. Uwuigbe, U., Jafaru, J. \& Ajayi, A. (2012). Dividend policy and firm performance: A study of listed firms in Nigeria. Journal of accounting and management information systems. 11(3), 442-454 